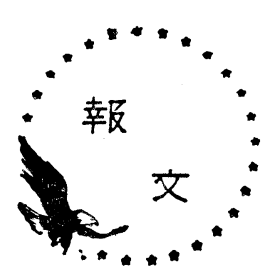

I . 緒

言

石炭の有効利用法の一部門として, 石炭の酸化分解 に関してはすでに広汎な報告1) 8) がある。幾多の酸化 法の中, アルカリ性酸化法は比較的有利に低分子の芳 香族酸を生成し得ることで近年とみに注目されている が，収率の見地から従来原料炭としては主に高炭化度 の瀝青炭が用いられている。しかし石炭の需要分布を 考慮すれば，治金および都市ガス工業に大きな役割を もつ溾青炭とは別に，低炭化度炭を此分野での利用対 象にするのも意義があると思われる。

低炭化度炭の化学組成は此較的芳香族炭素に乏しい ともいわれ，その見地からではそのままの酸化分野で は芳香族酸の収率が低いため, 酸化する前になんらか の処理を行なつて適度に芳香族炭素儿富む原料にすれ ばよい結果が得られると思われる。この目的では低温 乾留注有利な方法と考元られる。

コークスを原料とした酸化はさきに Howard 氏 ${ }^{9}$ らのごく簡単な記述があり, 神谷氏10)は本邦炭につい て報告しているが生成した水可溶芳香族酸の分析は $550^{\circ} \mathrm{C}$ 乾留炭のものについてしか述べられていない。

本報告は筆者がベンゼンポリカルボン酸を利用研究

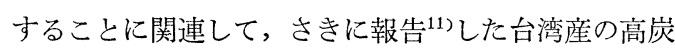
化度瀝青炭の酸化についで, 低炭化度炭ならびにその 乾留炭を酸化ならびに分析した結果を述べたものであ る。

\section{II. 実験方法}

1. 試 料

低炭化度原料炭として台湾瑞芳の深澳坑炭を採用し
た。さらにそれをFig. 1 亿示したような内容積 580

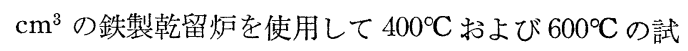
料乾留炭を造つた。乾留操作は, 原炭 $200 \mathrm{~g}$ を乾留炉 に入れて加熱を始めてから 1 時間で所要温度に達する ようにし, 所要の温度に 1 時間維持して行なつた。

2. 酸化反応

酸化は前報11を参照して, 内容積 $3 l$ のステンレス 製電磁上下攪找式オートクレーブを用い，それに 100 $\mathrm{g}$ 炭素相当の試料炭と $400 \mathrm{~g}$ の苛性ソーダを $1.5 \mathrm{l}$ の 水溶液にしたものを入れ，酸素をとおしながら温度 $255^{\circ} \mathrm{C}$, 圧力 $60 \mathrm{~kg} / \mathrm{cm}^{2}$, 時間 $2 \mathrm{hrs}$ の一貫した条件で 行なつた。

\section{3. 酸化生成物の分析}

酸化生成物の分析も前報の方法に準じた。すなわち 酸化反応後の固形物と溶液を沪別し，残渣から未反応 炭を定量し, 沪液からは炭酸ガスとシニウ酸を定量す る一方硫酸酸性にして水分不溶酸を沈澱させて分離定 量した。水不溶酸を除いた後の沪液はボウ硝の飽和溶 液にしてからメチルエチルケトンで水可溶酸を抽出定 量し，その中に含まれるシュウ酸を差引いて水可溶芳 香族酸とした。

かようにして得た水可溶芳香族酸はメタノールで繰 返しエステル化し，エチレンジクロリドとベンゼンの 混液で中性エステルを抽出分離して真空蒸留に付し て, まずベンゼンジカルボン酸, トリカルボン酸なら びにテトラカルボン酸を分別留出した。各留分につい てはペーパクロマトグラフィ12)を利用して成分を検定 した上で，エステルの状態でぬるいは塩酸でケン化し

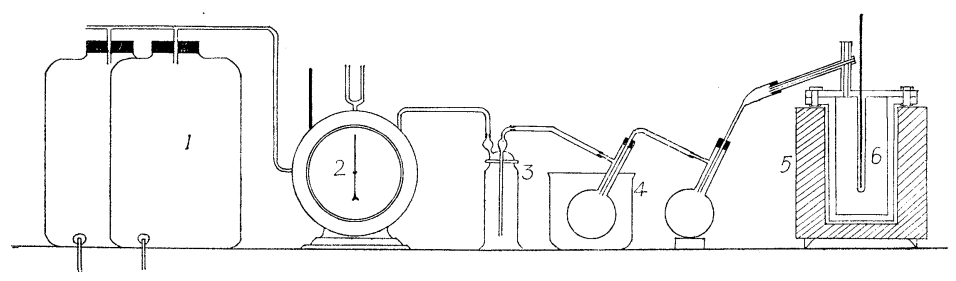

(1) Gas container

(2) Gas meter

(3) Drying bottle

(4) Tar receiver

(5) Electric heater

(6) Carbonization oven

Fig. 1 Carbonization Apparatus 
て酸の状態に戻し, 晶析法, 塩析法, 溶剤向流分配法 などを利用して各ベンゼンカルボン酸の分離定量を行 なつた。

\section{III. 結果および考察}

原炭ならびに上述のごとくにして得た乾留炭の性 状をTable 1 に, 乾留の際の生成物量をTable 2 に示し た。乾留炭を得るために使用した乾留炉 (Fig. 1) は 電気加熱炉で外囲より加熱するもので，攪挥装置がな い上に乾留温度は乾留炉の中央部で測定する型であつ たため，炉壁と炉心部との間にはだいぶ温度差が生ず るものと思われたが，実際にTable1.2表の数值よりみ ても $400^{\circ} \mathrm{C}$ で行なつた乾留は大体通常の低温乾留範囲

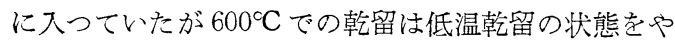
や超えていた。

これらの試料炭（いずれも $80 \mathrm{mesh}$ 通過）を酸化し て得た各生成物の無水無灰試料炭に対する割合を炭素

\section{Table 1 Oxidation Samples}

\begin{tabular}{|c|c|c|c|c|}
\hline & & $\begin{array}{l}\text { Raw } \\
\text { coal }\end{array}$ & $\begin{array}{l}400^{\circ} \\
\text { coke }\end{array}$ & $\begin{array}{l}600^{\circ} \mathrm{C} \\
\text { coke }\end{array}$ \\
\hline \multirow{4}{*}{$\begin{array}{c}\text { Technical } \\
\text { analysis } \\
(\%)\end{array}$} & Moisture & 2.93 & 1. 42 & 1.31 \\
\hline & Ash & 6.29 & 9.21 & 9.68 \\
\hline & V.M. & 43.97 & 16.73 & 7.19 \\
\hline & F. C. & 46.81 & 72.64 & 81.79 \\
\hline $\begin{array}{l}\text { Elementary } \\
\text { analysis }\end{array}$ & C. & 79.40 & 86.32 & 91.21 \\
\hline $\begin{array}{c}(\%) \\
\text { (a.d.f.) }\end{array}$ & $\mathrm{H}$. & 5.84 & 4.14 & 3.00 \\
\hline
\end{tabular}

Taale 2 Carbonization Products

(from $200 \mathrm{~g}$ of raw coal)

\begin{tabular}{|c|c|c|c|}
\hline & & $\begin{array}{l}\text { Carboni- } \\
\text { zation }\end{array}$ & $\begin{array}{l}\text { tempe- } \\
\text { rature }\end{array}$ \\
\hline \multicolumn{2}{|l|}{ Product } & $400^{\circ} \mathrm{C}$ & $600^{\circ} \mathrm{C}$ \\
\hline Coke & $\mathrm{g}$ & 134.3 & 120.1 \\
\hline Tar & $\mathrm{g}$ & 34.4 & 38.3 \\
\hline Water & $\mathrm{g}$ & 8.0 & 9.2 \\
\hline Gas & $l$ & 22.1 & 36.3 \\
\hline \multirow{3}{*}{ Gas } & Carbon dioxide & 8.2 & 7.1 \\
\hline & $\begin{array}{l}\text { Unsaturated } \\
\text { hydrocarbon }\end{array}$ & 6.8 & 5.1 \\
\hline & Oxygen & 7.4 & 2.3 \\
\hline Composition & Carbon monoxide & 0.4 & 0.6 \\
\hline \multirow[t]{3}{*}{ (volume \%) } & Hydrogen & 1.6 & 7.7 \\
\hline & Methane & 54.5 & 61.4 \\
\hline & Nitrogen & 21.1 & 15.8 \\
\hline Coke yield & wt \% & 67.2 & 60.1 \\
\hline
\end{tabular}

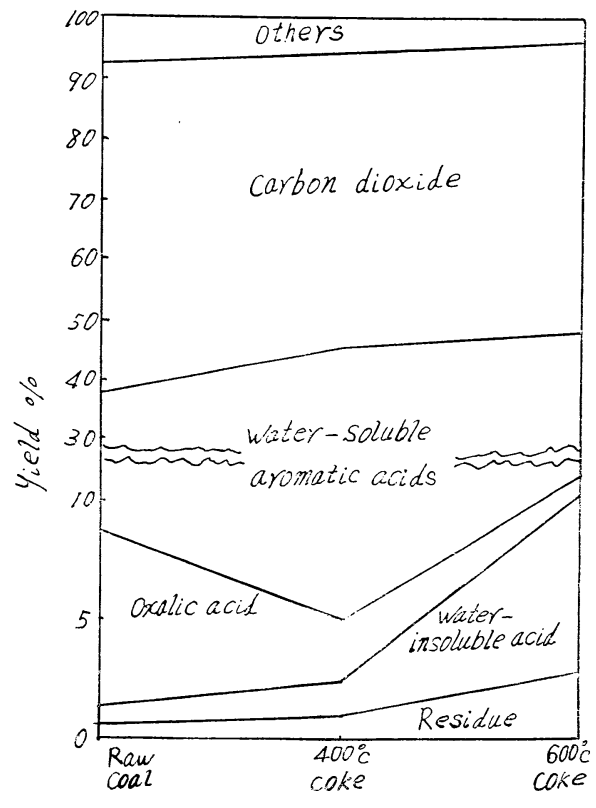

Fig. 2 Carbon distribution among Oxidation products

\section{Table 3 Analyses of aromatic acids}

Cabon Hydrogen E.W. M.W.

$\begin{array}{lllll}\text { Raw coal } & 51.05 & 3.56 & 76.5 & 253 \\ 400^{\circ} \mathrm{C} \text { coke } & 52.86 & 3.24 & 82.2 & 266 \\ 600^{\circ} \mathrm{C} \text { coke } & 53.34 & 3.17 & 86.0 & 269\end{array}$

分布で表わしたのが Fig 2 であり, Table 3 に各試料 炭より得られた水可落芳香族酸の性状を示した。一般 に, 低炭化度炭は高炭化度瀝青炭に比べて化学構造が 芳香族に乏しいため, 適度の酸化による芳香族カルボ ン酸の収率は瀝青炭のそれに比べて低いわけである が，本実験の結果でも原炭からの芳香族カルボン酸収 率は炭素で無水無灰試料炭に対して $29.2 \%$ しかなく, 従来の瀝青炭酸化報告が示す $40 \%$ 前後の収率に比べ て確かに低、值であつた。しかし $400^{\circ} \mathrm{C}$ おび $600^{\circ} \mathrm{C}$ の乾留炭からの収率はそれぞれ $39.8 \%$ と $36.2 \%$ であ り，瀝青炭の場合とほとんど変ら結果を得た。これ は Table 1からもわかるように，かような温度で乾留 して得た乾留炭は元素組成が瀝青炭のそれと似るばか りでなく，化学構造も歴青炭に似て芳香族に富むよう になることを意味すると思われた。また， $600^{\circ} \mathrm{C}$ 乾留 炭は $400^{\circ} \mathrm{C}$ 乾留炭に比べて水可溶芳香族の収率がやや 
劣り末反応炭と水不溶酸が多くなつたが，これはその 程度に乾留度が進むと芳香族構造がより発達して構造 単位内の芳香族縮合環がより多環になり本実験の酸化 条件汶しての化学反応性が低くなつた結果であると 考えた。
Table 4 はそれぞれの試料より得られた永可溶芳香 族酸に含まれていた各ベンゼンカルボン酸の量を水可 溶芳香族酸全量に対する重量％で示したものである が，安息香酸やペンター, ヘクサカルボン酸は收率が 非常に小さいために省略した。

\section{Table 4 Benzenecarboxylic acids in total aromatic acids}

Benzenecarboxylic acid

$$
\text { (wt. \%) }
$$

Dicarboxylic acid

Tricarboxylic acid $\left\{\begin{array}{l}1,2,3- \\ 1,2,4-\end{array}\right.$

Tetracarboxylic acid

Total
Raw coal
3.1
$10.8\left\{\begin{array}{c}40 \\ \ddot{60}\end{array}\right.$

26.6 $400^{\circ} \mathrm{C}$ coke

2. 4

$16.8\left\{\begin{array}{c}48 \\ . . \\ 52\end{array}\right.$

20.3

39.5

(25.7) $600^{\circ} \mathrm{C}$ coke

2.0

$9.4\left\{\begin{array}{c}61 \\ . \\ 39\end{array}\right.$

27.8

39.2

(24.1)
Note

$o-: m-: p-$

approximately $70: 20: 10$

No. 1, 3, 5

Mostly $1,2,3,4-$ $1,2,4,5-$

( ) Showing the percentage to original coal

Table から明らかなごとく, ジカルボン酸の収率は 原炭が最高で乾留度が進むにつれて減り, 一方卜リカ ルボン酸の収率は $400^{\circ} \mathrm{C}$ 乾留炭の場合が最高であつ た。さらに特徴を認められたことは，トリカルボン酸 異性体1，2，3-トリベンゼンカルボン酸対 $11,2 ， 4$-トリ ベンズンカルボン酸の収量が， $400^{\circ} \mathrm{C}$ 乾留炭を界とし て原炭と $600^{\circ} \mathrm{C}$ コークスの場合とでは $40: 60$ から 61 : 39に逆転していることであつた。すなわち乾留度が 進んだ乾留炭ほど $1,2,3$-トリベンゼンカルボン酸の 全トリベンゼンカルボン酸中に占める割合が増えた。 これらの結果は乾留炭の方が低炭化度原炭に比べて化 学構造的に鎖状部分が少なく, また乾留炭でも乾留度 が進んだものほど芳香族核が大きくなることをある程 度裹書きしたものと推察した。

Table3k水可溶芳香族酸の收率を無水無灰試料炭な らびに無水無㕄原料炭にする炭素の割合で表わした が，図からわかるように乾留炭からの収率は試料炭に 対して原炭のそれより明らかに高いばかりでなく，原 料炭ベースに換算しても原炭のそれに比べてわずかに 低、程度であつた。これ活すなわち, 石炭化学の観点 に立てば，低炭化度炭をそのまま酸化するよりも低温 で乾留して得た乾留炭を酸化した方が，乾留の過程に おいて得られるタールとガスの分だけ有利であること を示したものであると考えられた。

\section{N. 総 括}

台湾産の低炭化度炭一深澳坑炭一ならびにその乾留炭 を苛性ソーダ溶液中で酸素を使つて $255^{\circ} \mathrm{C}, 60 \mathrm{~kg} / \mathrm{cm}^{2}$, $2 \mathrm{hrs}$ の条件で酸化を行なつて水可溶芳香族酸を得た。

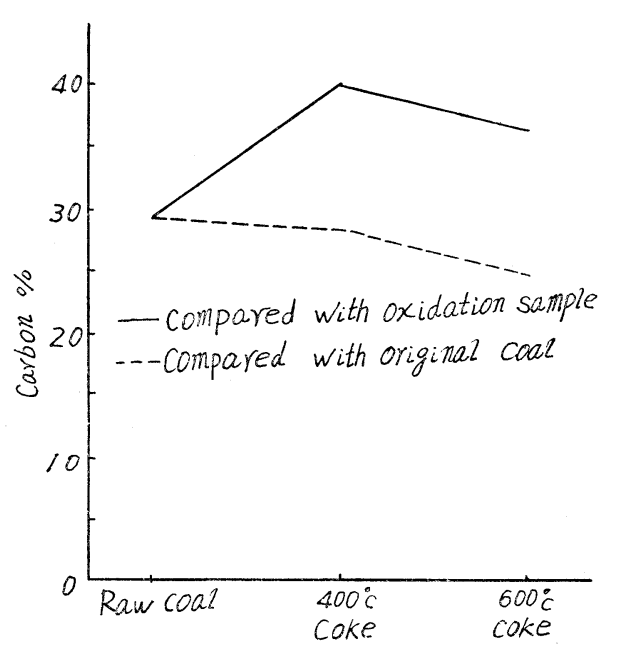

Fig. 3 Yield of Water-soluble aromatic acids

低炭化度炭からの水可溶芳香族酸の収率浪青炭の 場合汇比べて低く，無水無灰試料炭に対して炭素に換 算して $29.2 \%$ （その内ベンゼンジ-, トリー, テトラー カルボン酸 $18.3 \%$ ) であつたが，適度の低温乾留炭か らは $39.8 \%$ (その内ベンゼンジー, トリー, !テトラカ ルボン酸 $25.7 \%$ ) の高収率で通常の瀝青炭に少ら奴結 果を得た。

また, 低温乾留炭より得られた水可溶芳香族酸中の トリベンゼンカルボン酸の割合は従来のものに比べて 大きく,さらに乾留度の違つた乾留炭から得られたへ ミメリット酸とトリメリット酸の比率が変つた。 
かように乾留炭を酸化して高収率でしかもある程度 選択的に芳香族カルボン酸を製造し得るならば，乾留 ガスおよびタールの収量をも考え合わせて，これは低 炭化度炭の有力な石炭化学的利用法の一端であるとと もに石炭の化学構造解明にも役立つように思えた。

本実験を実施するために御援助いただいた安東新午 教授と神谷佳男講師に感謝の意を表わします。

\section{文献}

1) H. Strache et al, Kohlen Chemie, p. 289 (19 24)

2) O. Horn, Abhandl. d. Kohle, 8, 339 (1928 9)

3) D. H. Bangham, Progress in Coal Science, p. 282 (1950) Intersciene
4) H. C. Howard, Chemistry of Coal Utilization, 1, (1945) John Wiley

5) 樋口, 有合化, 11, 180 (1953)

6) 神谷, 有合化, 17, 109 (1959)

7) D. W. Krevelen et al, Coal Science p. 203 (1957)

8) 馬場, 太刀川 等, 石炭化学工業, p. 313 (1960) 産業図書

9) H. C. Howard et al, Ind. Eng. Chem., 44, 2784 (1952)

10) 神谷, 工化, 65, 382 (1962)

11) 石, 燃協誌, 42, 92 (1963)

12) K.G. Beck, Brennstoff-Chemie, 35, 275 (1954)

\title{
Studies on the Oxidation of a Lower-rank Coal and its Cokes
}

\author{
by Shih Jung-Wei
}

(Tokyo University)

SYNOPSIS :- Shen-ou-kang Coal, a kind of lower-rank coal produced in Taiwan, and its cokes obtained under different carbonisation temperatures were subjected to oxygenoxidation in caustic slurries. A comparison was made among those oxidation products, and low-temperature carbonized coke was found to be a good raw material for "coal acids" by no means inferior to a bituminous coal. By the way, it was thought to be helpful for investigating coal structures by such a treatment. 